\author{
Khalid Said Rabayah \\ Associate professor \\ Applied Informatics Research Center, Arab American University, Palestinian Territory, Occupied \\ khalid.rabayah@aauj.edu
}

\title{
INFORMATION TECHNOLOGY USE AND ACADEMIC ACHIEVEMENTS OF STUDENTS IN PRIMARY SCHOOLS
}

\begin{abstract}
The association between ICT diffusion and education is a subject of hot debate in both ICT and educational circles. Stances range from positive enthusiast, to skeptics, to disbelievers vis-a-vis the impact of ICT on students' achievements. The purpose of this paper is to investigate the presence of any correlation between students' academic achievements as recorded by Trends in International Mathematics and Science (TIMMS 2011) and the penetration of ICT in their schools and households, with focus primarily on computers and the Internet.

The paper relies on the analysis of the data published by the Trends in International Mathematics and Science Study (TIMMS 2011), international study center and the international association for the evaluation of educational achievements. Statistical data analysis will be employed to figure out whether there is any correlation between the penetration level of ICT and the students' score in math and science tests as recorded by the TIMMS 2011 international scale.

The analysis conducted within the scope of this research indicates the lack of any association between ICT use and students achievements in math and science subjects. Though the linkage between students' achievements is not a straightforward issue that can be uncovered via simple regression analysis, however, the results definitely indicate that employment of ICT in both schools and homes is an insignificant factor that can be easily offset by other major factors, like socio-economic conditions, instruction resources, teachers' capabilities, or cultural factors.
\end{abstract}

Keywords: ICT use; TIMMS Test; Students achievements; ICT in education; E-learning effectiveness.

\section{INTRODUCTION}

Since the onset of the use of different forms of media, information and communication technologies in education, there has been a passionate debate on whether these technologies have any impact on the effectiveness of educational systems, and ultimately on students' academic achievements. A major cause for this debate has to do with the inability of neither side to strongly back their argument. This debate escalates even further when it occurs in the context of developing countries where most educational systems lack basic resources, and turned to be ineffective. This research in some way is a contribution to this debate through searching for indications that associate ICT use with students' academic achievements, based on the International TIMMS 2011 exam scores, in which hundreds of thousands of students have participated.

The question this research tries to answer has to do with the association between ICT use at school level and achievements in subject specific tests. The test selected are the most prestigious and credible TIMMS tests, which are globally recognized among the best tools to assess academic progress. The research will rely on a macroscopic analysis of students' achievements results in science and math test and the level of their ICT use both at their schools and household level. Correlation between computer and Internet use and TIMMS scores in subject specific, mainly math and science, will be analyzed. 
The test allows students from grade 4 and grade 8 to participate. For the sake of our study, grade 8 has been selected, to ensure that students are mature enough in their computing skills and their abilities to use these skills to advance their education.

Literature Review. The World Bank information Technology Division (InfoDev) summarized the international community experience in using ICT for education as follows; "while impact on student achievements is still a matter of reasonable debate, nevertheless a consensus seems to argue that the introduction and use of ICTs in education can be useful to help promote and enable educational reform, (infoDev, 2005). This debate over the impact of ICT on education has resulted in research that produced varying results (e.g. see the review by Kulik, 2003).

Proponent of ICT in education argue that ICT make huge resources of information available for learners anytime anywhere, almost for free, and that is occurring at a pace that never been witnessed all throughout the history of humanity. However opponents of ICT in education claim that having these information sources available for students and people is something and utilizing them accordingly, e.g. in the course of education, is something else. Making information available for students will not attract them to act positively and transform this information into effective knowledge, as those researchers used to argue.

Pro- ICT people further argue that ICT use in school is crucial to equip students with the digital literacy skills needed for the information age, as suggested by Manuel Castells (Castells, 2009). These technologies can also be effective to improve understanding of difficult to grasp concepts, through the use of multi-modal and media representations, (M. Selinger, 2009). This argument is used by several sources to maintain that ICT can indeed be used to raise students' achievements, and therefore justify expenditure inflicted by these technologies. Some proponents of ICT in education even went beyond these arguments, for instance Sugata Mitra (2006) to claim that ICT can compensate for poorer quality teachers especially in rural areas. Many other proponents see ICT as a catalyst to reform pedagogy that was difficult to achieve through traditional means (Cornu, 1995, Joshi and Murthy 2004).

In opposition to that, there are groups who think that ICT is not a universal solution that can work in any context, and the use of ICT in teaching and learning is very much interrelated with the context, culture, values and people, who should act on these technologies to make them effective, since technology alone cannot make the difference as stated in Toyama, K. (2011), and Rabaya'h K. (2013).

Other researchers are moderate in their view in regards to ICT impact on education. They argue that these technologies amplify existing institutional and human factors, and do not create new ones, [Philip E. Agre (2002)]. There is no agency to technology, the agency should be to humans, and technology just has a magnifying effect. Technology cannot change human intent, human intent should be first in place then technology can take a role.

Defenders of the ICT use in education claim that ICT can stimulate learning on the individual level, particularly when implemented in a student-centered approach. Some other studies revealed that computer use can be more helpful for high achieving students when other educational resources are made available for them (ibid.). However, people of different nationalities and culture have different teaching and learning style, and therefore their comprehension and interaction with ICT tools are different, (K. Rabayah 2013, Selinger, 2004). This is why we should not consider ICT to impact educational systems the same way and to the same degree for all cases.

The use of ICT at school level and its prospective to facilitate teaching and learning has started to receive exceptional attention in educational circles in the last two decades (Eickelmann, 
2011). In that respect two streams of research can be classified; firstly, learning how to use ICT and to equip learners with the 21st century skills (Cox, 2008, Fraillon \& Ainley, 2009), and secondly, understanding how ICT-use can affect students' academic achievement (Voogt, 2008, Eickelmann \& Schulz-Zander, 2008).

There are few baseline studies that can be cited in the area of monitoring and evaluating the impact of ICT on education and students performance, especially in the developing countries context. Farrell and Isaacs (2007) conducted a study that focused on the ICT-centered interventions in Africa. Wagner (2005) considers that there is a well-known ignorance of the consequences or impact of ICTs on education goals and targets. Unwin T. (2005), confirms the same argument and reveals that a relevant and credible knowledge in that area is needed to help policy makers make effective decision on the use of ICT for education.

On the theoretical level, scholars seem to agree on the potential benefits of ICT in education. In that regard they created long list of rationales for the use of IT in education, among them; social, vocational, pedagogical, catalytic, ICT industry, and the cost effective rationales, (J. Voogt, 2008). However, the issue among those scholars is not the potentiality of these technologies but rather the actual impact on students' performance, on which they seem to disagree. According to Dynarski et al. (2007), it is very difficult to provide convincing evidences on the impact of ICT on students' performance, and this is due to the fact that the use of ICT requires the mastery of complex cognitive skills, which cannot be measured by means of standardized tests. This trend is emphasized by Voogt \& Knezek (2008), who assert that the confusion related to the contribution of ICT to students performance, has to do with the gap between intended, implemented, and attained curriculum. They stressed that there is substantial degradation in what has been attained, in contrast to what has been implemented and intended. They also tend to refer part of the difficulty in assessing the attained curriculum to the difficulty of measuring it using the standardized tests.

As far as basic education is concerned, two of the main targeted rationales are the social and pedagogical. In social rational the intention is to teach students how to be fluent in using ICT, while pedagogical is meant to teach how to use ICT to learn and acquire better knowledge and experiences. However, research has shown that teaching ICT as a separate subject will not help in using ICT effectively for learning academic concepts, since that will result in decontextualized approach. Therefore they call for teaching ICT skills through their use in teaching other academic subjects, (Hammond \& Mumtaz, 2001). Other researchers, e.g. Watson (2001), believe that it is very difficult to do that since it requires teachers ability to cope with the social, pedagogical and catalytic rationales, which according to her create conflicting demands for teachers.

Scholars debate the role that ICT is supposed to contribute to education. Dede (2008) in his book described these roles per educational theory. The behaviorists believe ICT is better used to attune to the individual characteristics of learners, while cognitive theories demand to use ICT to cope with complex concepts and skills that cannot be attained by traditional means. Constructivists' theories on the other hand, assume that learners will use ICT to construct their knowledge and skills through active participation in the learning processes.

The consensus is that integrating ICT in the curricula is not a straightforward issue, and it requires the employment of huge resources, even in countries with high GDP. In that respect, Becker (2000) found that in many European countries and North America, the integration of ICT in the curriculum was hardly realized. Having access to computers does not mean that students are using these computers at all. The OECD (2006) study revealed that out of 32 countries participated in the PISA assessment international test, 10 countries use computers frequently, at 
least few times per week at school. For example, Van Kessel et al. (2005), investigated the use of computers in the Netherlands between 1997 and 2005, and reported that ICT is used mainly for word processing, browsing the web, and messaging.

As for the use of ICT in Math and Science classes, Cox and Webb (2004) described the best ways ICT is used in math, science, art and social sciences. He claims that the best way to exploit ICT in math classes is when it is used to facilitate mathematical reasoning and support connecting math ideas with the real world, and the best way to use these technologies to teach science is when they are used to visualize phenomena and processes, which could not be demonstrated to students other ways. Researchers like (Becta, 2001; Harrison et al., 2002; Christmann et al., 1997), believe that the use of ICT to teach science may have greater impact than other subjects, and the extensive use of ICT might result in improved attainment, (Christmann et al., 1997). However, (Alspaugh, 1999; Baggott La Velle et al., 2003) found no clear evidence on students' achievements for classes making more use of ICT in science classes. In contrast, Webb (2008) published an extensive review on the use of ICT in science education, and concluded that ICT has very limited impact on students' achievements. Among the reasons he emphasized; the availability of appropriate hardware and software, the difficulty in employing various technologies in the curriculum, and the teachers attitudes and competences to effectively employ these technologies.

As for math, most of the analysis reports found either no or negligible impact. Kulik (2003) studied the impact of ICT on teaching math, in addition to other disciplines, and found that even well-prepared and integrated learning systems slightly improved students' math scores. Dynarski et al. (2007) in their report to the US congress described the impact of commercial educational software on reading and math. They observed that test scores of classrooms who assigned to use software products did not vary from test scores in control classrooms by statistically significant margins. Cox et al. (2003) reported on a positive relationship of the use of ICT and students learning of specific math concepts and skills. However, these positive changes were found in only small scale and focused studies. The OECD (2006) report showed some level of correlation between math performance of 15 years old students and their access and use of computers. The same report found no clear association between mathematics performance and frequency of computer use. The report found that students with high and low of computer use scored lower than did students who had medium level of computer use. Eickelmann, et al. (2012) conducting an analysis in three countries in three different continents, Australia, Singapore, and Germany. Her analysis arrived at conflicting results with no clear trends in the relation between ICT and math scores in TIMMS. A newly published paper from the same research team in Germany, Eickelmann, et al. (2014) using the 2011 TIMMS exam results, arrived at conflicting results in regards to the impact of the digital media of grade 4 students' achievements in math and science. The author came to the conclusion that the use of computer at home is not a facilitating factor for achievement in math and science in all countries. According to (ibid) the conflicting results are related to the very heterogeneity of the computer related policies of participating countries, and the missing link between technological, pedagogical, and content knowledge of teachers.

Generally speaking, in most cases of the use of ICT in education, initiatives start with high potential for curriculum, however, ended in big disappointment. For example, Nachmias et al. (2008) investigated 174 initiatives for using ICT in curriculum, and found that only in $18 \%$ of them, ICT influenced curriculum content and goals.

\section{RESEARCH METHODOLOGY}


This research is devoted to address the question of the effectiveness of ICT on students' achievements as revealed by TIMMS results of the year 2011. In general, there are two main approaches to undertake this issue; self-assessment studies which survey the educational actors being students, teachers, and school administrators, and examining the students' academic achievements using test results. In literature it is mentioned that most research rely on educational actors self-assessments, and most of these reports declare positive trends, see for example Trucano, Michael (2005). In this research the strategy is to focus on the correlation between the degree of ICT deployment and the students' achievements as revealed by the TIMMS universal standard exams. TIMMS is administered by the international association for evaluation of educational achievements (IEA), and it is considered by far the most prestigious and reliable academic achievement testing organization in math and science.

The paper will rely on the latest TIMMS results of the year 2011, where 63 countries ranging from rich to poor participated. Nearly 900,000 students sat for the exam. Recently IEA started to involve teachers, school administrators, and parents in filling out questionnaires to help out understanding students achievements trends. TIMMS targeted students in the 4th and 8th grade with over 150 items measuring their knowledge and understanding in numbers, geometry, algebra data analysis and so forth.

The present research makes use of the published TIMMS results of 2011, as presented by Mullis, et al. (2012). As of the year 1995, IEA started to survey participating schools for their incorporation of ICT in teaching and learning processes. TIMMS 2011 score sheets incorporated degree of computer incorporation in classes, which allows researchers to investigate potential correlation between achievements in covered subjects and degrees of computer penetration in the participating schools.

Data obtained from the TIMMS were statistically analyzed using the Statistical Package for the Social Sciences SPSS. Regression analysis was performed to data of different countries and correlation between the different countries students' performance in math and science and the level of ICT use in their countries were investigated.

\section{RESEARCH ANALYSIS AND RESULTS}

The paper will proceed through posing a series of hypothesis regarding the correlation between the use of ICT and students' achievements. Regression results based on the data collected from the TIMMS 2011are utilized to test whether these hypotheses can be supported. We relied on the collected data from Mullis, et al. (2012) which depicts students' achievements from the participating countries versus some factors as of the latest test results of the year 2011 .

First hypothesis we wish to examine is whether there is a correlation of certain degree between students' performance in math and science and the level of PC penetration at their schools. The indicator used to represent the PC penetration is the PC to students' ratio as reported by the school principals. The TIMMS authority has discretized computer usage into 4 levels; 1-2 students per PC, 3-6 students per PC, larger than 6 students per PC, and No PCs. The percentage of students' falls in each level is recorded by the organizers alongside of their exam results. 


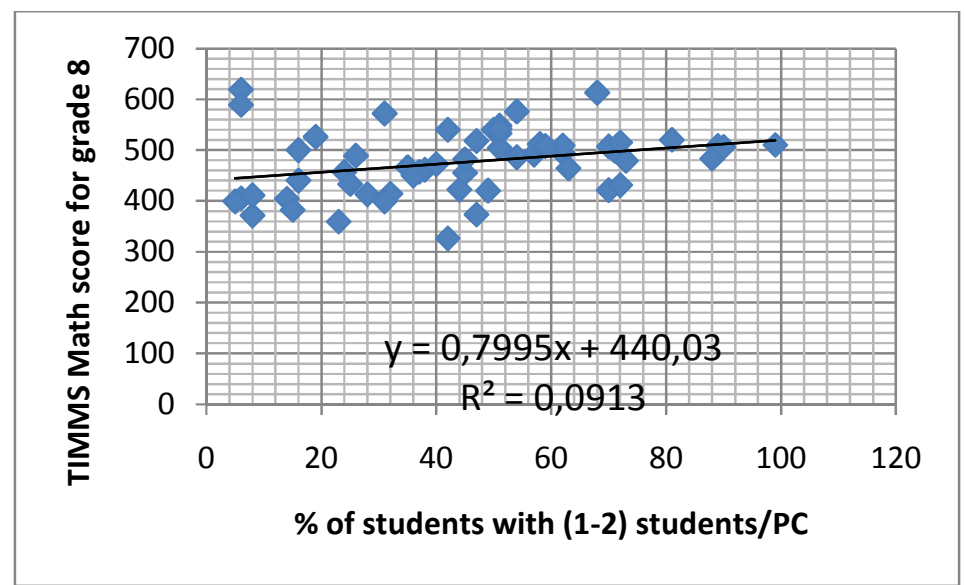

Figure 1: Correlation between grade 8 students' achievement in the TIMMS score for Math and the percentage of students with availability of 1 PC for 1-2 students for instruction at school.

Figure 1 above summarizes the recorded results of students with the highest computer penetration, i.e. 1-2 students per PC, and their average achievements in the TIMMS math test for grade 8 . The figure undoubtedly depicts no association of any kind between PC penetration level and TIMMS scores with a correlation square (R2) calculated to 0.09 .

Remark the wide range of values around the regression line both along the TIMMS scores (vertical axis) for a certain level of PC penetration, and along the PC penetration (horizontal axis) for certain TIMMS score. For instance, there are countries who achieved a score of 500 points in TIMMS with PC penetration of $15 \%, 30 \%, 40 \%, 60 \%, 80 \%$, and even $100 \%$. The best fit (or trend) line crosses the y-axis at 440 point, which theoretically means that 440 can be achieved at $0 \% \mathrm{PC}$ penetration.

The former experiment was conducted where the majority of countries took part in the assessment, yet, people might argue that only students in resourceful countries to whom all educational resources are made available might be affected by the presence of ICT at their schools. To test this thesis, the following experiment was devised. In this experiment, only countries who achieved 500 and above were selected. The hypothesis we are testing is that students who achieved higher in TIMMS are more affected with the presence of computers and IT than others. Results and scores of 14 countries fulfil the conditions are depicted in figure 2 .

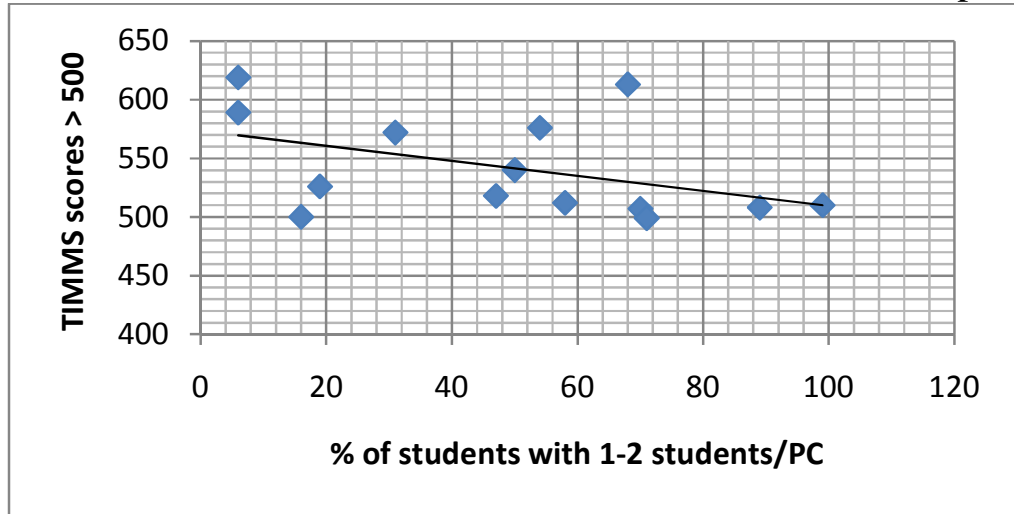

Figure 2: Correlation between grade 8 students' achievement in the TIMMS score for Math and the percentage of students with availability of 1 PC for 1-2 students for instruction for the 4th highest countries. 
Yet again the result shows no sign that higher PCs penetration scored high. Higher percentage of PC privileged students does not have any significance on the average of their achievement. The trend is even reversed, such that countries with higher PC penetration recorded lower scores. A correlation of -0.51 is calculated, showing anti-correlation.

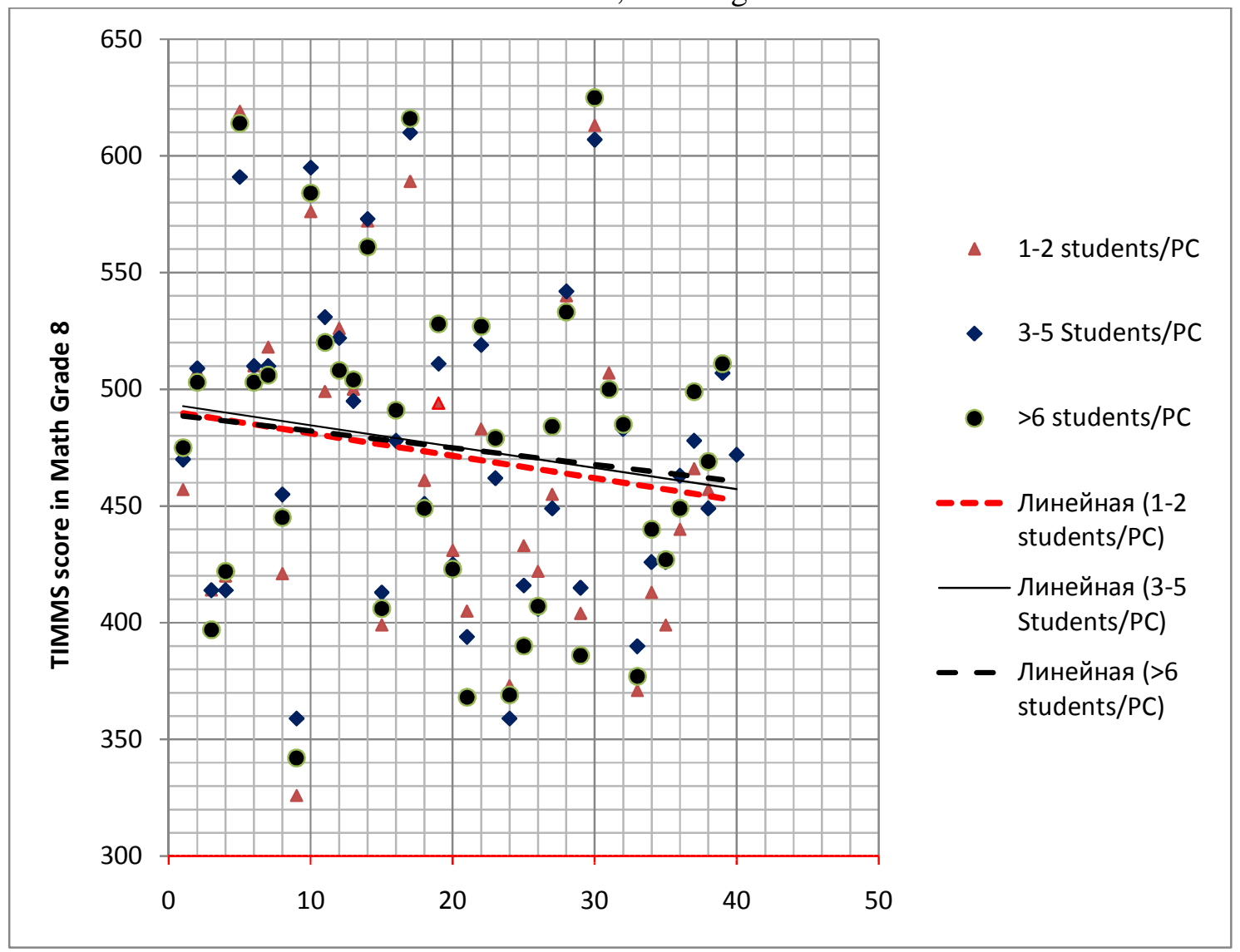

Figure 3: Association of availability of computers at school for instructions and TIMMS score of Math exam for grade 8.

To gain further insight into the impact of ICT on students' achievements and to test the preceding results in a way to generalize them, we analyzed the students' achievements trends versus wide range of students-to-PC ratios. Figure 3 above illustrates the correlation between the percentage of students with 1-2 PC, 3-6, and >6 PCs and their TIMMS scores in math at the 8th grade. Once more no correlation can be inferred. What is remarkable about this diagram is that the trend lines that represent each level are almost lying on top of each other's, which additionally emphasizes our initial findings that there is no clear association between computer use and students' achievements. In fact, the line which represents the best student-to-PC ratio lies below the two others.

So far association is tested across different countries, however, some people might argue that it is not wise to contrast different countries with each other's as they might have different settings, cultures, beliefs, practices, etc. Thus, testing each country records in regards to the correlation of PC penetration and TIMMS score might infer a more realistic image. This leads us to a new hypothesis which states that higher penetration of PCs at school of the same country leads to better TIMMS scores. 
It is very easy to test that based on figure 3. The marks that represent the computer penetration level are that line on top of each other's, where the triangle represents the $1-2$, the diamond represents the 3-5, and the solid black circles represent the $>6$ students per PC. Again there are no clear trend in how these marks are lining up, which further indicate that the difficulty in securing correlation between computer penetration level and students score in Math.

Table 1

Correlation between average students' achievement and the level of computer usage for instruction in their schools as revealed by the TIMMS scores for grade 8

\begin{tabular}{|l|c|c|}
\hline \multicolumn{1}{|c|}{ Country } & $\begin{array}{c}\text { Average TIMMS } \\
\text { score }\end{array}$ & $\begin{array}{c}\text { Correlation between TIMMS score and } \\
\text { computer usage }\end{array}$ \\
\hline Armenia & 457 & -0.968619605 \\
\hline Finland & 518 & 0.912870929 \\
\hline Georgia & 421 & -0.686742834 \\
\hline Ghana & 326 & 0.17740106 \\
\hline Hong Kong & 576 & -0.419313935 \\
\hline Italy & 500 & -0.755928946 \\
\hline Jordan & 399 & -0.042640143 \\
\hline Korea Rep. & 589 & -0.952216581 \\
\hline
\end{tabular}

To further test the same hypothesis, a new experiment was designed, in which a random sample of countries was picked up from the 63 different participating counties. Students-to-PCs ratios have been correlated with their achievements in Math tests as reported in table 1. The table shows no clear trend in results, as most countries have exhibited anti-correlation relation. Among the tested countries, Finland indicated a high degree of correlation between PC penetration in their schools and the TIMMS scores they achieved in math. On the contrary, Korea, which scored the highest in math, exhibited anti-correlation with a correlation value of almost (-1), which indicates higher penetration of PC at their school is associated with lower TIMMS scores.

What has been discussed so far applies only to the students results in grade 8 math tests. Thereof, a valid question would be whether the preceded results apply to science scores for the same grade. The results of the correlation between student-to-PC ratio and their science TIMMS scores for grade 8 are reported in figure (4). Once again, what has been revealed for math is applicable for science. Correlation is hardly seen in the diagram, and the correlation square factor is less than 0.1, quite far from the true correlation square factor of 1 .

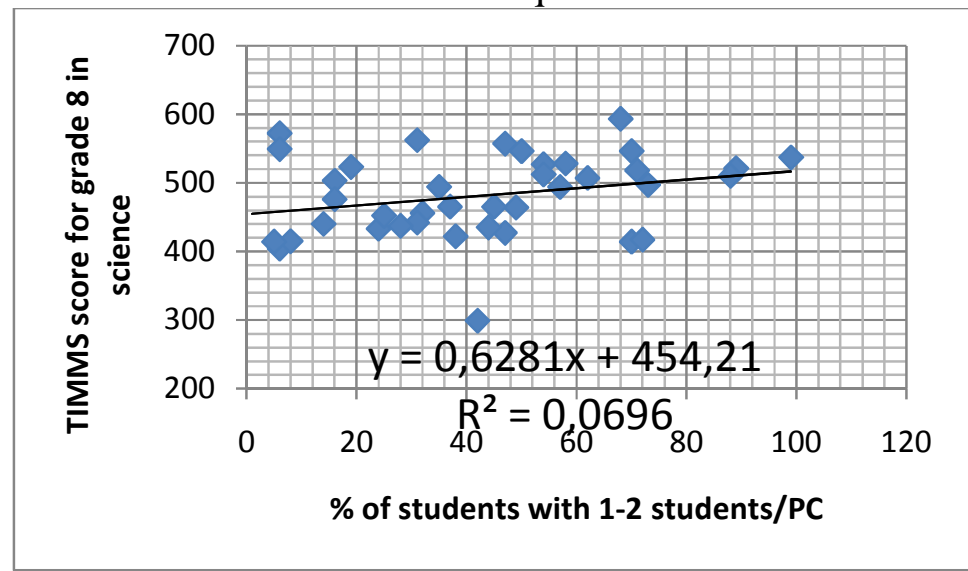

Figure (4): Correlation between grade 8 students' achievement in the TIMMS score for Science and the percentage of students with availability of 1 PC for 1-2 students for instruction at school. 
Thus far there has been no evidence of correlation between computer use at school and students achievement for both science and Math. However one might argue that the invisible impact has to do with the restrictions placed by school's authority on the PCs and Internet use by students. This is why some people are debating that the use of computers at home might have more pronounced impact on students achievements than it is at school. To examine that, a new experiment is designed to measure any possible correlation between students' achievements versus PC and Internet use at household. Results were depicted for grade 8 science subject in figure 5 , and math in figure 6.

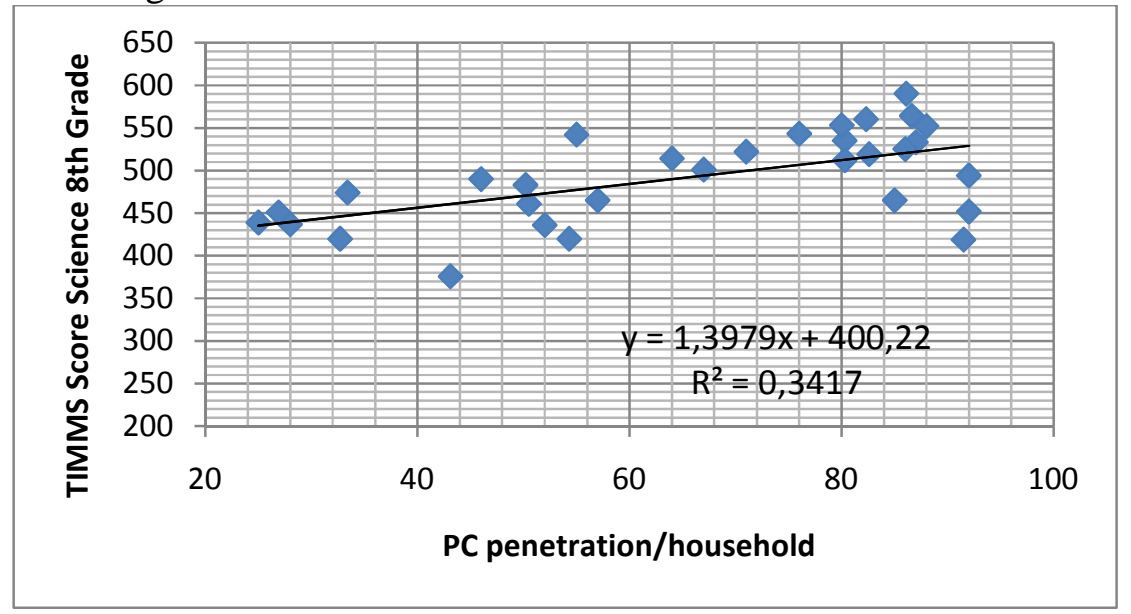

Figure (5) Correlation between grade 8 science TIMMS scores and the level of PC penetration per household

It is quite unmistakable from the figure that there is a sort of correlation between the two parameters in the sense that the higher the PC penetration per household the higher the TIMMS results. Remark that a value of $\mathrm{R} 2$ of 0.34 indicates a small correlation between TIMMS scores and the PC penetration. In figure (6) a correlation between TIMMS science score and the Internet penetration per household is depicted.

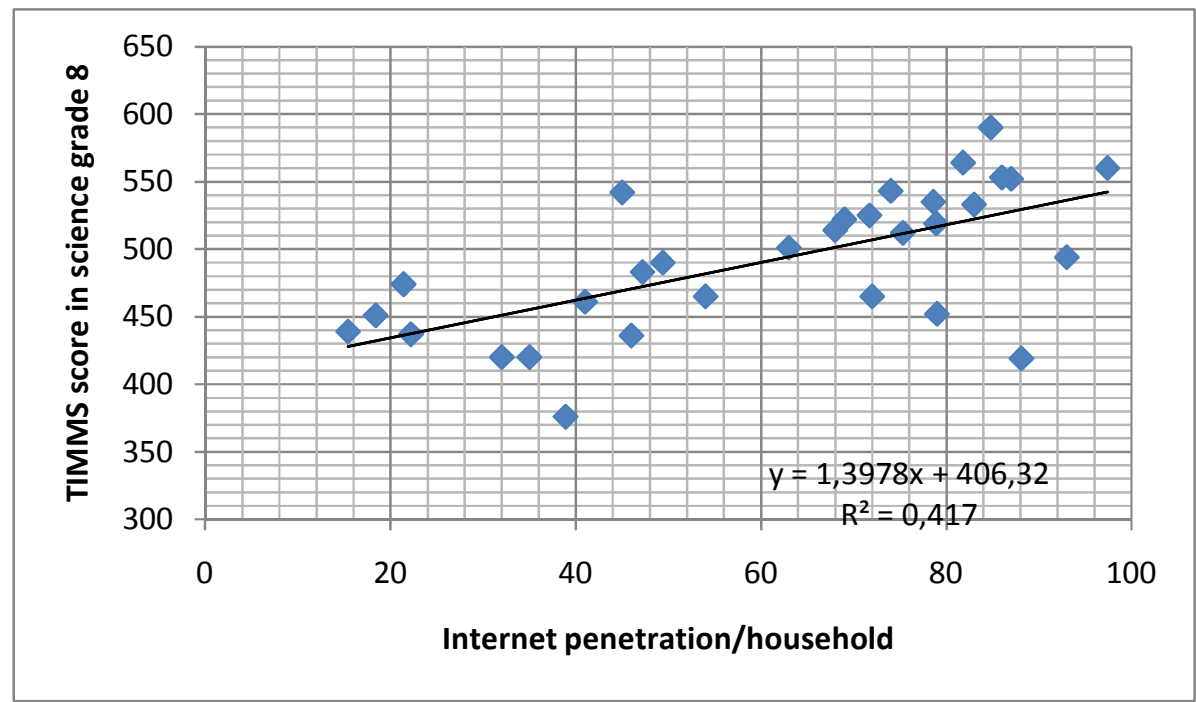

Figure (6) Correlation between grade 8 science TIMMS scores and the level of Internet penetration per household 
Yet again it is evident that there is a sort of correlation between the TIMMS scores and the Internet penetration per household. $\mathrm{R} 2$ value of 0.42 is recorded in this case, which is reasonably high enough to state the existence of correlation. This result is somewhat in contradiction with result recorded for the correlation between TIMMS scores and ICT penetration at school. One possible explanation is that household PC and Internet penetration reflects socio-economic status of students' families which is pronounced by their TIMMS scores. Remark that participating students were asked to fill in an information sheet which includes information on their ownership of PC and Internet among other issues. But we have to be careful that association of the two indicators does not mean causation, i.e. it is not because PC's and Internet penetration are high per household is the reason behind their achievements of high scores.

\section{DISCUSSION}

The present research discusses the preliminary results of a study dedicated to assess the association between the use of ICT at school and students' achievements, as measured by their scores in math and science of the TIMMS 2011 international tests. Though the tests are organized for the 4th and the 8th grades, the research efforts focus on the 8th grade alone. The research team believes that 8th grade students are more mature in their ICT proficiency to advance their knowledge than they are in grade 4.

It is reasonably apparent from the preceding analysis that association between computer use at school and student TIMMS score is missing in most regression tests done in the course of this research. This basically means that frequent use of computers at schools for instruction is not manifested in the students' achievements. This conclusion applies to both math and science scores for the 8th grade for the 62 countries contributed in TIMMS and covered by the study. The same conclusion was reached when the results of the best performing countries were analyzed. Testing the best performing countries was conceived to test the hypothesis which states that ICT can only contribute to improve students' performance with whom all or most other needed requirements, such as teaching resources, teacher development, libraries, etc., to achieve high scores are made available.

In an attempt to eliminate other distracting uncontrolled parameters from the study, and to analyze schools from the same cultural and environmental settings, similar association tests were performed for participants from the same country. These tests yet again revealed no correlation of any significance. Some results even indicated anti-correlation between computer usage and students' achievement in both math and science.

It is quite hard to explain these results based on the data provided by the TIMMS 2011 report, however, the researcher will try to explain the results trends based on his experience in the use of ICT within his local context, the Palestinian context. Remark that the author is working as a consultant for the ministry of education in the field of ICT employment in education. The most crucial issue which determines how ICT impacts students' performance is decided by how these technologies are employed by schools. One possible explanation of the results is that the use of ICT at school in most cases is meant to advance students skills in using ICT rather than using these tools to advance their knowledge and understandings in subject matters. It is believed that in most schools ICT use is not linked to pedagogy (Becker 2000, Dynarski 2007). This is confirmed by many reports and most importantly, the InfoDev (2005) report which clearly stated that positive impact is more likely when linked to pedagogy, and ICT can have positive effects on student achievement when ICTs are used appropriately to complement a teacher's existing 
pedagogical philosophies, (Trucano, M. (2005). Van Kessel et al. (2005) clearly stated that in a country like Netherlands, the use of ICT is limited to word processing, browsing the web, and email rather than for pedagogical targets.

The additional cause which impacts the use of ICT by school students has to do with the time available for students to use these technologies. We believe that students do not have time, long enough, to impact their scores in international tests in subjects like math and science. For instance, in Palestinian schools, students use computers for two to three hours a week to teach basic computer skills. This entails that the per-students time per week is less than one hour, as 23 students per PC is the typical scenario in public schools. Other reports like (Nachmias el al. 2008, Webb 2008, Voogt 2008, OECD 2005, OECD 2006), confirm this claim.

Results inferred from these tests clearly assert no association of any kind between ICT school resources and students achievements as revealed by TIMMS 2011data. Yet, this does not absolutely refute the association between ICT and academic achievements. Some people might argue that at school students do not have the necessary time and freedom of use of these technologies to advance their education, and when it happens that they have the needed time and resources their attainments will be improved. This fact is emphasized by many reports, for instance, OECD (2005) has shown that students use of ICT at school is considerably less than at home.

To test these arguments, the correlation between ICT use at household and TIMMS scores is inspected. Contrary to former results, a positive correlation was found between household computer penetration and academic achievements, as indicated by figures 5 and 6 above. A correlation value of 0.65 was calculated for Internet, and 0.58 for computers in household. These results clearly reveal a correlation of some kind, though moderate, between ICT and students achievements. Eickelmann, et al. (2014) using the 2011 TIMMS exam results, arrived at the same results using TIMMS 2011 data for grade 4, where computer use at home positively affects the school children scores in math and science.

At this point in the investigation a valid question pops up; why there has been no correlation between computer use at school and students achievements, but a correlation was found between computer use at home and students' achievements. Remark that the study has included more than 60 countries of different socio-economic conditions. Even though there has been some degree of association, we have to be cautious in referring to causation; i.e. to refer improvement in TIMMS scores to the increase in computer home use by students. There could be other factors that can be counted for the increase in TIMMS scores, and accompany the increase in penetration of ICT in household. This sometimes referred to as indirect or (secondary) association between the two parameters, a state when the association is recorded not because there is a direct link between the two tested factors, but because of the presence of another (hidden) factor, called co-founding factors. We speculate that the factor that happens to co-exist with the increased penetration of ICT at home is the socio-economic condition of students. It is quite known that ICT penetration is highly correlated to the socio-economic conditions as indicated by many international studies, see (Chinn \& Fairlie, 2010) and references therein.

Luckily, the TIMMS report included students' socio-economic conditions as a parameter, reflected in three levels; affluent, moderate and disadvantaged. Figure (7a) depicts TIMMS scores for countries as a function to the percentage of affluent students in that country. And figure (7b) depicts the TIMMS scores for countries as a function of percentage of disadvantaged students in their schools. 


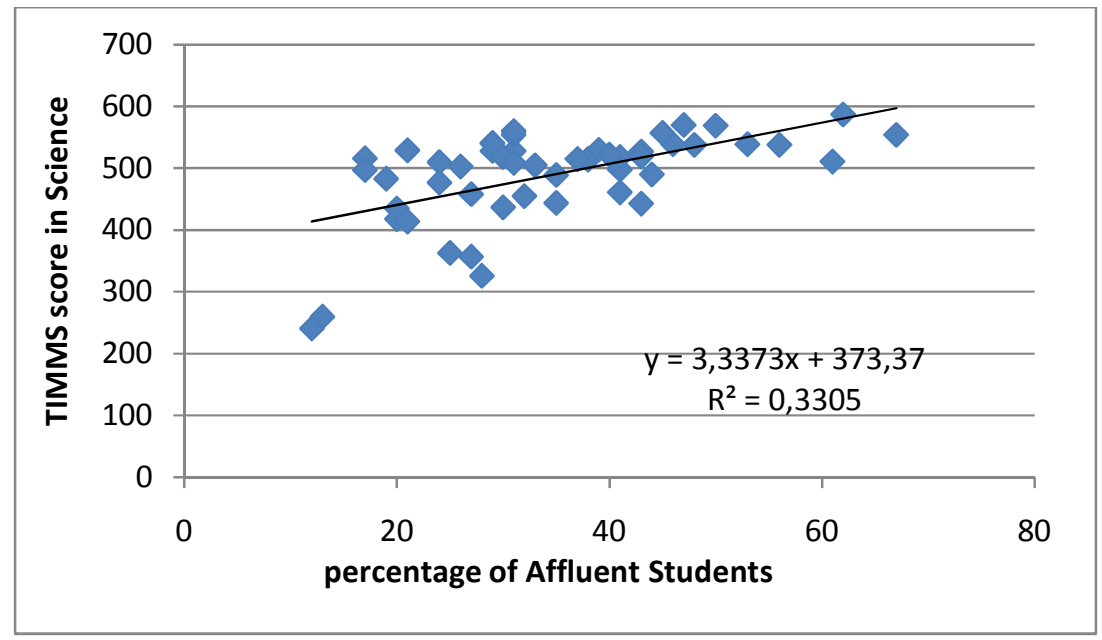

Figure (7a): TIMMS score in Science for grade 8, as a function of percentage of affluent students.

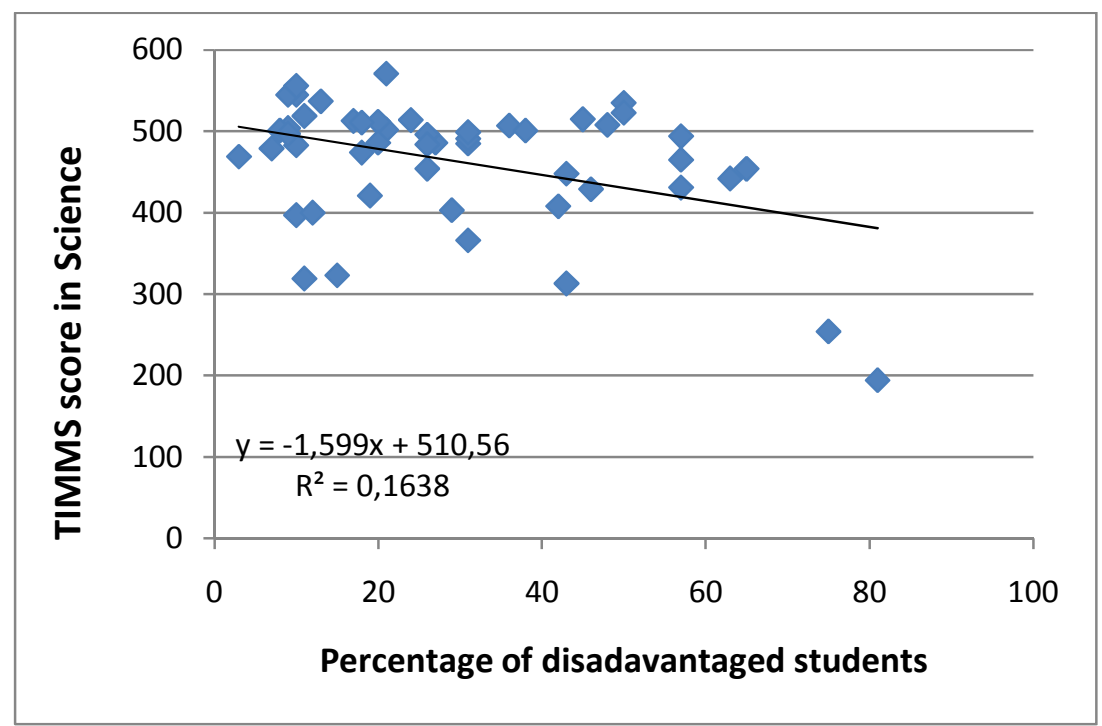

Figure (7a): TIMMS score in Science for grade 8 as a function of percentage of disadvantaged students.

As indicated by TIMMS report, the socio-economic condition of the students' families is among the factors which influence the students TIMMS scores. It is reported in by Mullis et al. (2012) that there is an increase of 119 points in the Math exam between students belong to families with plenty of resources, and those belong to families with few resources. Students belong to rich families who scored higher in TIMMS science and math tests, are definitely capable of owning a PC and connecting to the Internet, and this might explain why students with high PC and Internet penetration achieved higher scores.

The impact of ICT on Math and Science education requires further investigation at the microscopic level to be able to state whether ICT has a real and significant impact on academic performance. From the above results it is very hard to conclude that the presence and use of these technologies does impact students' achievements. Having computers at home and connecting to the Internet is something and using these technologies for education purposes is something else. 
We do believe that using ICT to achieve better results requires employing several resources, through complex processes than just learning how to use these technologies. As reported by OECD (2005), enormous factors frustrate the implementation of ICT in curriculum, and this is mainly due to the fact that the use of ICT requires the mastery of complex cognitive skills.

\section{CONCLUSION}

In this research the impact of the use of ICT both at school for instructional purposes and at home for general use is investigated based on the published data by the TIMMS 2011 international exam authorities. The analysis findings fail to support any significance correlation between ICT use and average students' achievements. This conclusion applies to the rich industrialized countries and the poor developing countries as well, and it is applied when all participating countries are counted for, as well as analysis within the same participating countries. In many cases, frequent use of computers for instructional purposes led to lower TIMMS score both in math and science.

It is to be remarked here that the issue of detecting the impact of ICT use on students' achievements is not that easy job, since students' achievement is a multifactorial causation process that has so many interrelated parameters. Some parameters might be stronger than ICT, and work to offset its influence on students' scores, and this is why it was not easy to detect it throughout the analysis of the TIMMS results. However, we were encouraged to do the analysis since there are several other parameters with an impact that is so apparent on students' TIMMS performance such as library size, teaching conditions, availability of resources, family economic condition, etc.

The fact that we fail to establish an association between the use of computers at schools and students achievements does not undermine the significance of ICT as an independent skill that is needed to be mastered by every single student nowadays. ICT is indeed a basic skill that should be professionally taught to any students as it is needed in all facets of life, not only to achieve higher level of educational achievements. In the 21 st century, ICT skills or what is called digital literacy is an undivided part of every country educational system and it is crucial as is reading, writing, and arithmetic skills.

\section{REFERENCES}

1. InfoDev (2005) Knowledge Maps: ICT in education. What do we know about using technology effectively in education in developing countries? Washington, DC; World Bank

2. Castells, Manuel. Communication power. Oxford University Press, 2009.

3. Selinger, Michelle. ICT in education: Catalyst for development. Cambridge University Press, Cambridge, 2009.

4. Voogt, J., \& Knezek, G. (2008). International handbook of information technology in primary and secondary education (Vol. 20). Springer.

5. Kulik, J. A. (2003). Effects of using instructional technology in elementary and secondary schools: What controlled evaluation studies say. Arlington, VA: SRI International.

6. Dynarski, M. (2007). Effectiveness of reading and mathematics software products findings from the first student cohort: report. DIANE Publishing.

7. Voogt, J., \& Knezek, G. (2008). International handbook of information technology in primary and secondary education (Vol. 20). Springer.

8. Hammond, M., \& Mumtaz, S. (2001). How trainee teachers of IT approach teaching their subject. Journal of Computer Assisted Learning, 17(2), 166-176. 
9. Watson, D. M. (2001). Pedagogy before technology: Re-thinking the relationship between ICT and teaching. Education and Information technologies, 6(4), 251-266.

10. Dede, D. (2008). Theoretical perspectives influencing the use of information technology in teaching and learning. In J. Voogt \& G. Knezek (Eds.), International handbook of information technology in primary and secondary education. New York: Springer.

11. Becker, H. J. (2000). Findings from the teaching, learning, and computing survey: Is Larry Cuban right? Revision of a paper written for the January 2000 School Leadership Conference of the Council of Chief Officers, Washington, DC.

12. van Kessel, N., Hulsen, M., \& van der Neut, I. (2005). 8 jaar onderwijs en ICT [8 years education and ICT]. Retrieved 18 May 2006 from http://www.ict-onderwijsmonitor.nl/.

13. Cox, M. J., \& Webb, M. E. (2004). ICT and pedagogy: A review of the research literature. Coventry and London: British Educational Communications and Technology Agency/Department for Education and Skills.

14. Becta. (2001). A preliminary report for the DfEE on the relationship between ICT and primary school standards. Coventry: Becta.

15. Harrison, C., Comber, C., Fisher, T., Haw, K., Lewin, C., Lunzer, E., McFarlane, A., Mavers, D., Scrimshaw, P., Somekh, B., \& Watling, R. (2002). ImpaCT2. The impact of information and communication technologies on pupil learning and attainment. Department for Education and Skills, London. Retrieved May 18, 2006, from http://www.becta.org.uk/page_documents/research/ImpaCT2_strand1_report.pdf.

16. Christmann, E., Badgett, J., \& Lucking, R. (1997). Microcomputer-based computer-assisted within different subject areas: A statistical deduction. Journal of Educational Computing Research, 16(3), 281-296.

17. Alspaugh, J. W. (1999). The relationship between the number of students per computer and educational outcomes. Journal of Educational Research, 21(2), 141-150.

18. Baggott La Velle, L., McFarlane, A., \& Brawn, R. (2003). Knowledge transformation through ICT in science education: A case study in teacher-driven curriculum development-Case-Study 1. British Journal of Educational Technology, 34(2), 183-199.

19. Nachmias, R., Mioduser, D., \& Forkosh-Baruch, A. (2008). Innovative practices using technology: The curriculum perspective. In J. Voogt, \& G. Knezek (Eds.), International handbook of information technology in primary and secondary education. Berlin Heidelberg New York: Springer.

20. Kulik, J. A. (2003). Effects of using instructional technology in elementary and secondary schools: What controlled evaluation studies say? Arlington, VA: SRI International. Retrieved 18 May 2004 from http://www.sri.com/policy/csted/reports/sandt/it

21. Mitra, Sugata, Ritu Dangwal, and Leher Thadani. "Effects of remoteness on the quality of education: A case study from North Indian schools." Australasian Journal of Educational Technology 24.2 (2008): 168-180.

22. Cornu, Bernard. "Teacher Education and Communication and Information Technologies: Implications for Faculties of Education." Information technologies in teacher education: issues and experiences for countries in transition (1995): 93.

23. Joshi, I. and Murthy, T. (2004) Paradigm change: effect of ICTs on modern education. I4d (http://www.i4donline.net/issue/march04/education.htm)

24. Agre, Philip E. "Real-time politics: The Internet and the political process." The information society 18.5 (2002): 311-331.

25. Eickelmann, Birgit, et al. (2012) "ICT-use in primary schools and children's mathematics achievement-a multi-level approach to compare educational systems through an international lens with TIMMs data." Joint AARE APERA International Conference, WERA focal meeting, Sydney 2012.

26. Eickelmann, Birgit. "Supportive and hindering factors to a sustainable implementation of ICT in schools." Journal for educational research online 3.1 (2011): 75-103.

27. Voogt, Joke M., and Gerald A. Knezek, eds. International handbook of information technology in primary and secondary education. Vol. 20. Springer, 2008.

28. Cox, Margaret J. "Researching IT in education." International handbook of information technology in primary and secondary education. Springer US, 2008. 965-981.

29. Fraillon, J., \& Ainley, J. (2009). An international study of computer and information literacy (ICILS). Melbourne: Australian Council of Educational Research.

30. Schulz-Zander, R., \& Eickelmann, B. (2009). Teacher Collaboration Concerning ICT-Use and its Essential Conditions. WCCE.

31. Selinger, M., \& Gibson, I. (2004). Cultural relevance and technology use: ensuring the transformational power of learning technologies in culturally defined learning environments. In World Conference on Educational Multimedia, Hypermedia and Telecommunications (Vol. 2004, No. 1, pp. 5310-5317). 
32. Khalid Rabayah (2013), Arab Learners Cultural Values and Their Interference with E-Learning , Conference proceeding of 5th international Computer Supported learning Education Conference, Aachen6-8 May 2013 Germany.

33. Farrell, G., Isaacs, S., Trucano, M., Hamdy, A., Hare, H., Tetang Tchinda, J., ... \& Fall, B. (2007). Survey of ICT in Education in Africa, Volume 2: 53 Country Reports.

34. Wagner, D. A., Day, B., James, T., Kozma, R. B., Miller, J., \& Unwin, T. (2005). Monitoring and evaluation of ICT in education projects. A handbook for developing countries. Washington DC: infoDev. Retrieved July, 7, 2006.

35. Unwin, T. (2005). Towards a framework for the use of ICT in teacher training in Africa. Open Learning: The Journal of Open, Distance and e-Learning, 20(2), 113-129.

36. Trucano, Michael. 2005. Knowledge Maps: ICTs in Education. Washington, DC: infoDev / World Bank.

37. Toyama, K. (2011). There are no technology shortcuts to good education. Educational Technology Debate, infoDev-UNESCO. Retrieved from http://edutechdebate. org/ict-in-schools/there-are-no-technologyshortcuts-to-good-education.

38. Mullis, I. V., Martin, M. O., Foy, P., \& Arora, A. (2012). TIMSS 2011 international results in mathematics.

39. Chinn, M. D., \& Fairlie, R. W. (2010). ICT use in the developing world: an analysis of differences in computer and internet penetration. Review of International Economics, 18(1), 153-167.

40. Eickelmann, B., Drossel, K., Wendt, H., \& Bos, W. (2012). ICT-use in primary schools and children's mathematics achievement-a multi-level approach to compare educational systems through an international lens with TIMSS data, WERA focal meeting in Sydney in 2012.

41. Birgit Eickelmann, Mario Vennemann, Julia Gerick, \& Ramona Lorenz (2014), Computer and Internet in primary Mathematics and Science Education and its Relationship with Student Achievement - International Findings from TIMSS 2011. Proceedings of the American Educational Research Association annual meeting (AERA), Philadelphia, PA, and aera14_proceeding_684105.pdf.

Матеріал надійшов до редакиії 30.09.2014 p.

\title{
ВИКОРИСТАННЯ ІНФОРМАЦІЙНИХ ТЕХНОЛОГІЙ І НАВЧАЛЬНІ ДОСЯГНЕННЯ УЧНІВ ПОЧАТКОВОЇ ШКОЛИ
}

\author{
Халід Саід Рабаях \\ доцент Дослідницького центру прикладної математики \\ Арабо-американський університет, Палестина \\ khalid.rabayah@aauj.edu
}

\begin{abstract}
Анотація. Зв'язок між поширенням ІКТ та освіти є предметом гарячих дебатів в IКТ та освітніх колах. Існують досить різні думки: від позитивних ентузіастів до скептиків та тих хто не вірить у вплив ІКТ на досягнення учнів. Метою даної роботи є дослідити наявність будь-якої кореляції між академічними досягненнями учнів, як це описано у міжнародному порівняльному дослідженні якості природничо-математичної освіти учнів 4-х та 8-х класів TIMMS 2011, i проникнення IКТ в школи і побут, з акцентом в першу чергу на комп'ютери та Інтернет .

Стаття базується на аналізі даних, опублікованих міжнародним дослідженням TIMMS 2011, Міжнародним центром дослідження та Міжнародної асоціації з оцінки навчальних досягнень. Статистичний аналіз даних буде використовуватися, для того щоб з'ясувати, чи є кореляція між рівнем проникнення IКТ та тестових оцінках учнів з математикиі та природничих наук, які відображені за міжнародною шкалою TIMMS 2011.

Аналіз, проведений в рамках даного дослідження, вказує на відсутність будь-якого зв'язку між використанням IКТ і досягненнями учнів з математики та природничих наук. Хоча зв'язок між досягненнями учнів не є простим питанням, яке може бути розкрито через простий регресійний аналіз, однак, результати виразно вказують, що застосування IКТ в школах і у побуті $\epsilon$ незначним фактором, який може бути легко компенсовано іншими основними факторами, такими як: соціально-економічнимі умови, ресурси 3 інструкцій, можливості вчителів, культурні чинники.
\end{abstract}


Ключові слова: використання IKT; тести TIMMS; навчальні досягнення учнів; IКT в освіті; ефективність електронного навчання.

\title{
ИСПОЛЬЗОВАНИЕ ИНФОРМАЦИОННЫХ ТЕХНОЛОГИЙ И УЧЕБНЫЕ ДОСТИЖЕНИЯ УЧАЩИХСЯ НАЧАЛЬНОЙ ШКОЛЫ
}

\author{
Халид Саид Рабаях
}

доцент Исследовательского центра прикладной математике

Арабо-американский университет, Палестина

khalid.rabayah@aauj.edu

\begin{abstract}
Аннотация. Связь между распространением ИКТ и образования является предметом горячих дебатов в ИКТ и образовательных кругах. Существуют самые разные мнения: от положительных энтузиастов до скептиков и тех., кто не верит влиянию ИКТ на достижения учащихся. Целью данной работы является исследовать наличие любой корреляции между академическими достижениями учеников, как это описано в международном сравнительном исследовании качества естественно-математического образования учащихся 4-х и 8-х классов TIMMS 2011, и проникновение ИКТ в школы и быт, с акцентом в первую очередь на компьютеры и Интернет.

Статья базируется на анализе данных, опубликованных международным исследованием TIMMS 2011, Международным центром исследования и Международной ассоциации по оценке учебных достижений. Статистический анализ данных будет использоваться для того, чтобы выяснить, есть ли корреляция между уровнем проникновения ИКТ и тестовых оценках учащихся по математикие и естественным наукам, которые отражены по международной шкале TIMMS 2011.

Анализ, проведенный в рамках данного исследования, указывает на отсутствие всякой связи между использованием ИКТ и достижениями учащихся по математике и естественным наукам. Хотя связь между достижениями учащихся не является простым вопросом, который может быть раскрыт через простой регрессионный анализ, однако, результаты определенно указывают, что применение ИКТ в школах и в быту является незначительным фактором, который может быть легко компенсирован другими основными факторами, такими как: социально-экономические условия, ресурсы с инструкциями, возможности учителей, факторы культуры.
\end{abstract}

Ключевые слова: использование ИКТ; тесты TIMMS; учебные достижения учащихся; ИКТ в образовании; эффективность электронного обучения. 